\title{
The use of latex biomembrane in mandible vestibuloplasty: a case report
}

\section{O uso de biomembrana de látex natural em vestibuloplastia de mandíbula: relato de caso clínico}

\author{
Gustavo Otoboni Molina* \\ Marcelo Tomás de Oliveira** \\ Jefferson Ricardo Pereira** \\ Janaina Salomon Ghizoni*
}

\section{Abstract}

Introduction: the latex biomembrane Biomembrana ${ }^{T M}$ has been used in several medical specialties with promising results in promoting wound healing, including surgical, traumatic, isquemic and pressure-induced, as well as ulceration of varied etiology. However, in dentistry its use is not currently well established. Objective: the aim of this study was to describe a treatment for vestibuloplasty using a latex membrane. Case report: due to the inherent characteristics of the latex biomembrane (Biomembrana ${ }^{T M}$ ), a vestibuloplasty of the anterior sextant of the mandible was performed using Arruda's technique of second intention healing modified by the use of a latex biomembrane, in order to assess its applicability and ability to maintain the depth of the vestibule in this type of surgery. Final considerations: latex membrane is an easy to use material which proved useful for vestibuloplasty, since it provided gain of attached gingiva, which remained stable during the 9-month follow-up period.

Keywords: Latex. Oral surgery. Guided tissue regeneration, periodontal. Vestibuloplastia.

\section{Introduction}

Vestibuloplasty is a muco-gingival procedure designed to increase the amount of attached gingiva and vestibule depth ${ }^{1,2}$. Although the ideal height of attached gingiva is a controversial issue, there are specific applications for this therapy, such as to hault progressive gingival recession, regain attached gingiva and increase the depth of the vestibule, which aid bacterial plaque control and increase resistance to mastication trauma ${ }^{3,4}$. It can also be indicated for esthetic reasons and to create a plateable surface (in edentulous patients) in order to increase denture retention and stability ${ }^{5,6}$. Furthermore, it can prove useful in cases of inflammatory alterations and tissue recession around implants caused by a taut fraenulum insertion, i.e., the general health of the soft tissues surrounding an implant $^{4}$.

Excessive bone loss due to traumatic exodontia, bone resorption secondary to periodontitis and alveolar ridge atrophy following extractions are local contra-indications to vestibuloplasty ${ }^{5}$. Therefore in the case of an edentulous mandible, bone height and width, as well as muscle and mucosal insertions must be sufficient to warrant significant gain $^{2}$, because when the mandible height is lower than $20 \mathrm{~mm}$, the mental nerve may be subjected to intensive prosthetic pressure, in which case techniques for alveolar ridge augmentation and implants should take priority ${ }^{6}$. 
There are several surgical techniques for vestibuloplasty, which can be divided into 4 groups: submucosal, second intention healing, transposition of flaps and grafts ${ }^{2}$. Furthermore, technical resources such as carbon dioxide lasers ${ }^{7}$, alloplastic materials ${ }^{2}$ and membranes designed to cover and protect the surgical wound and optimize healing.

Amongst the techniques for second intention healing, the Arruda method ${ }^{2}$ was used in this study, which consists in the repositioning of muscle and mucosa. However, this type of procedure tends to lead to contraction and consequent reduction in sulcus depth, as a result of the long standing proliferation tissue in open areas ${ }^{2}$.

The latex membrane (Biomembrana ${ }^{\mathrm{TM}}$ ) is a translucent biomaterial obtained from the polymerization of natural latex with preservation of the spacial configuration of its native proteins as well as the reorganization of its proteophospholypids. Such particular architecture allows adherence to protein and stimulation of the adhered cells, especially the macrophages involved in healing. ${ }^{9}$ It is recommended for optimizing healing in both clean and infected wounds such as diabetic wounds, varicose ulcers, pressure sores, traumatic and surgical wounds. Conversely, it is contra-indicated for people with known allergy to latex and in the case of neoplastic lesions ${ }^{10}$. It has also been used to aid healing in cases of chronic ulcers of varied etiology, isquemic ulcers in several body sites ${ }^{11}$, myringoplasty ${ }^{12}$, reconstruction of defects in the abdominal wall and peritoniotomy ${ }^{13}$, etc.

Based on findings in the literature regarding latex membranes applications, its efficacy and relatively low use in dentistry, we report a case of vestibuloplasty using Arruda's Technique ${ }^{2}$ modified by the use of latex membrane (Biomembrana ${ }^{\mathrm{TM}}$ ), in order to assess its suitability in dentistry by observing its ability to maintain the depth of the buccal sulcus after healing. This study was approved by the Universidade do Sul de Santa Catarina (Unisul) Ethics Committee - reference number 07.176.4.02.III.

\section{Case report}

Sixty one-year-old caucasian female seeked the Unisul's multidisciplinary dental clinics for periodontal and prosthetic treatment. The patient was generally fit and healthy, however dentally compromised due to chronic periodontitis with pockets of up to $6 \mathrm{~mm}$ in the upper arch and $8 \mathrm{~mm}$ in the lower and generalized bleeding on probing. She presented with standing upper anterior and lower anterior teeth as well as lower first premolars only, with marked gingival recession in the canines. The patient was given basic periodontal treatment by means of root planning and plaque control instruction as well as prosthetic rehabilitation using partial upper and lower dentures.

Due to the presence of marked gingival recession associated with a shallow lower anterior sulcus, a vestibuloplasty was deemed appropriate in this case (Fig. 1). Measurements of the attached gingiva on the labial aspect of the teeth were taken by subtracting the distance between the marginal gingival line and the muco-gingival junction by the probing depths (Table 1) prior to surgery.

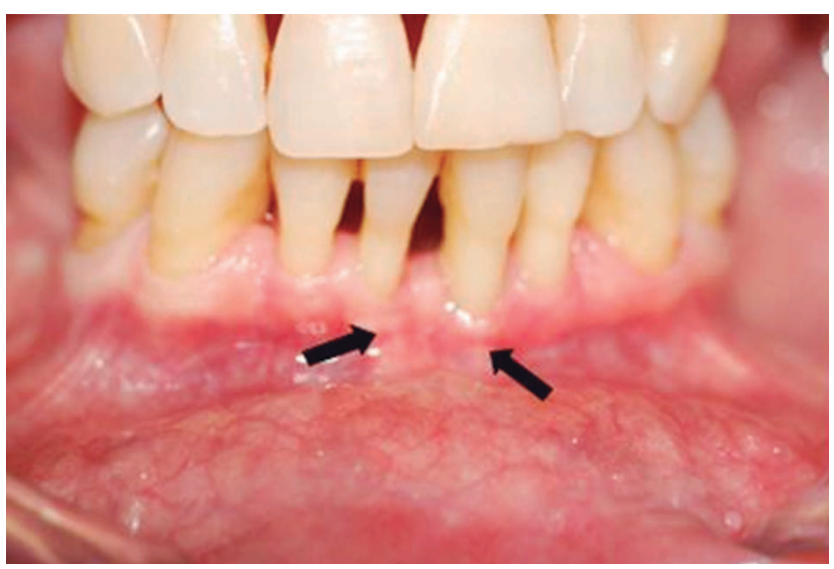

Figure 1 - Initial presentation - note gingival insertion close to the gingival margin (as indicated)

Table 1 - Attached gingiva measurements ( $\mathrm{mm}$ ) before vestibuloplasty (pre-op), at suture and membrane removal visit (15 days post-op) and 9 months after surgery

\begin{tabular}{|c|c|c|c|c|c|c|c|c|c|c|c|c|c|c|c|c|c|c|}
\hline \multirow[b]{2}{*}{ Tooth } & \multicolumn{6}{|c|}{ Pre-op measurement (mm) } & \multicolumn{6}{|c|}{15 days post-op (mm) } & \multicolumn{6}{|c|}{9 months post-op (mm) } \\
\hline & 43 & 42 & 41 & 31 & 32 & 33 & 43 & 42 & 41 & 31 & 32 & 33 & 43 & 42 & 41 & 31 & 32 & 33 \\
\hline Attahced Gingiva (mm) & 4 & 4 & 2 & 1 & 5 & 4 & 8 & 9 & 6 & 5 & 8 & 9 & 8 & 9 & 5 & 4 & 8 & 9 \\
\hline
\end{tabular}

Arruda's ${ }^{1}$ surgical technique modified by the use of a biomembrane was carried out as follows: following bilateral mental nerve block, an incision (blade 12) was made along the muco-gingival junction perpendicular to the alveolar bone surface (Fig. 2). Careful supraperiosteal dissection permitted the detachment of the labial and mental muscle insertions. A latex biomembrane (Biomembrana ${ }^{\mathrm{TM}}$, Biocure $^{\mathrm{TM}}$ - Membrana Natural de Cicatrização, Pe- lenova Biotecnologia S.A., São Paulo) was placed covering the surgical wound and it was stabilized by several individual sutures (4-0 Vycril, Ethicon, Johnson \& Johnson. Brazil) along the middle part of the membrane to the periosteum, which would then become the bottom of the sulcus. Subsequently, peripheral sutures were placed to ascertain full wound coverage (Fig. 3). 


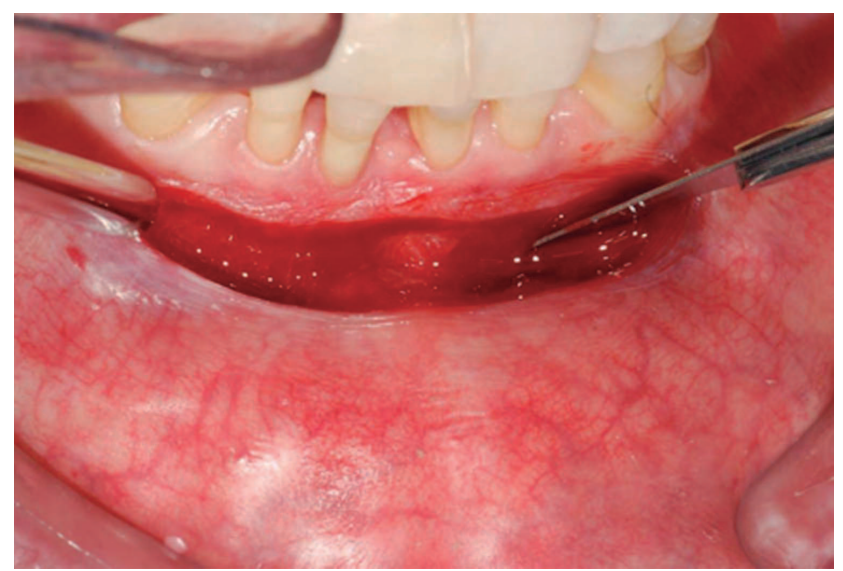

Figure 2 - Supraperiosteal incision, perpendicular to the alveolar ridge

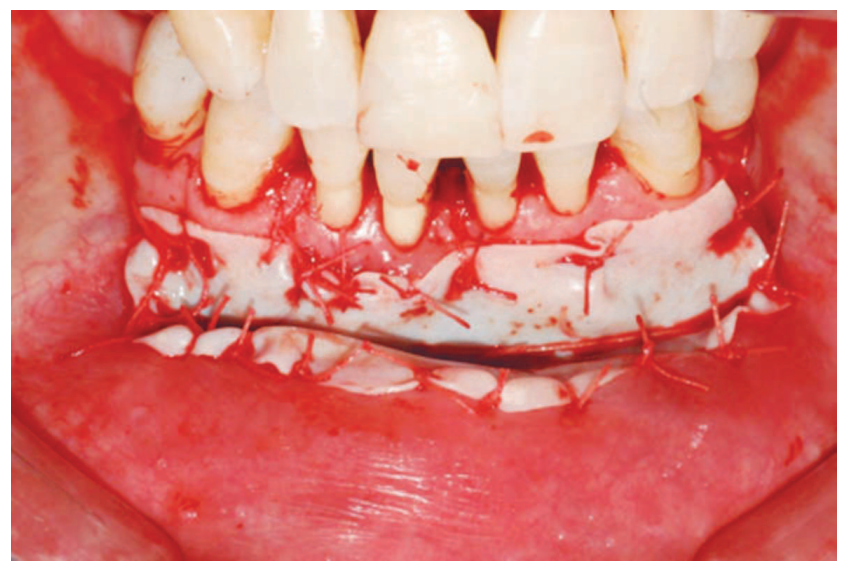

Figure 3 - Biomembrana ${ }^{T M}$ stabilized using central sutures (lowermost sulcus point) as well as peripheral sutures

The patient was prescribed $500 \mathrm{mg}$ of Amoxicillin every 8 hours for 7 days, nimesulide $100 \mathrm{mg}$ every 12 hours for 3 days, paracetamol $750 \mathrm{mg}$ every 6 hours and $0.12 \%$ chlorhexidine mouthwash.

Seven days post-surgery the following were observed: the membrane did not retain rests of food, the mucosa-biomembrane margins presented granulation tissue of normal appearance clinically (Fig. 4) and the subjective evaluation of the patient with regards to pain and comfort was positive.

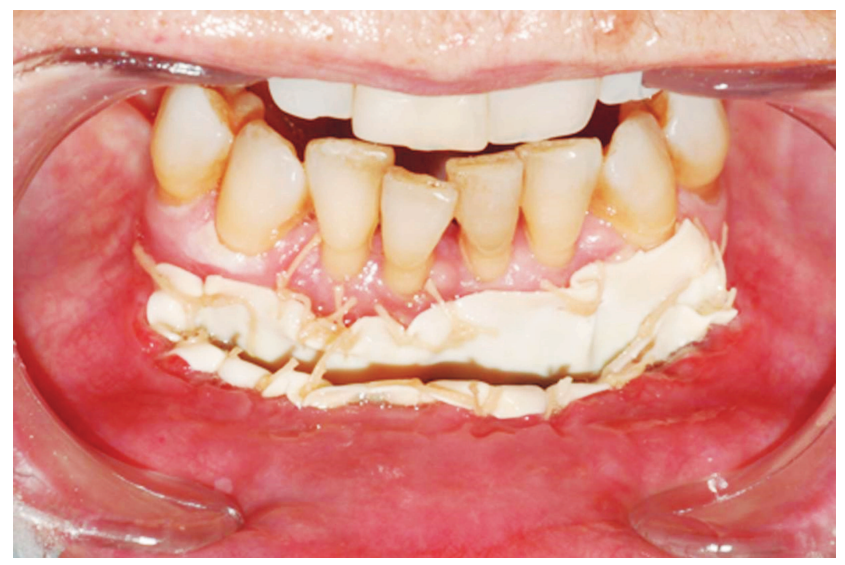

Figure 4 - Biomembrana ${ }^{\text {TM }}$ appearance after 1 week
On the 15th day the biomembrane was removed. Some sutures had already been resorbed and the surgical wound presented completely healed. The patient was instructed to perform oral physiotherapy exercises at home, which consisted in downward traction of the labial and mental musculature.

Immediately after membrane removal and 9 months post-vestibuloplasty new measurements of attached gingiva were taken (Table 1) and (Fig. 5).
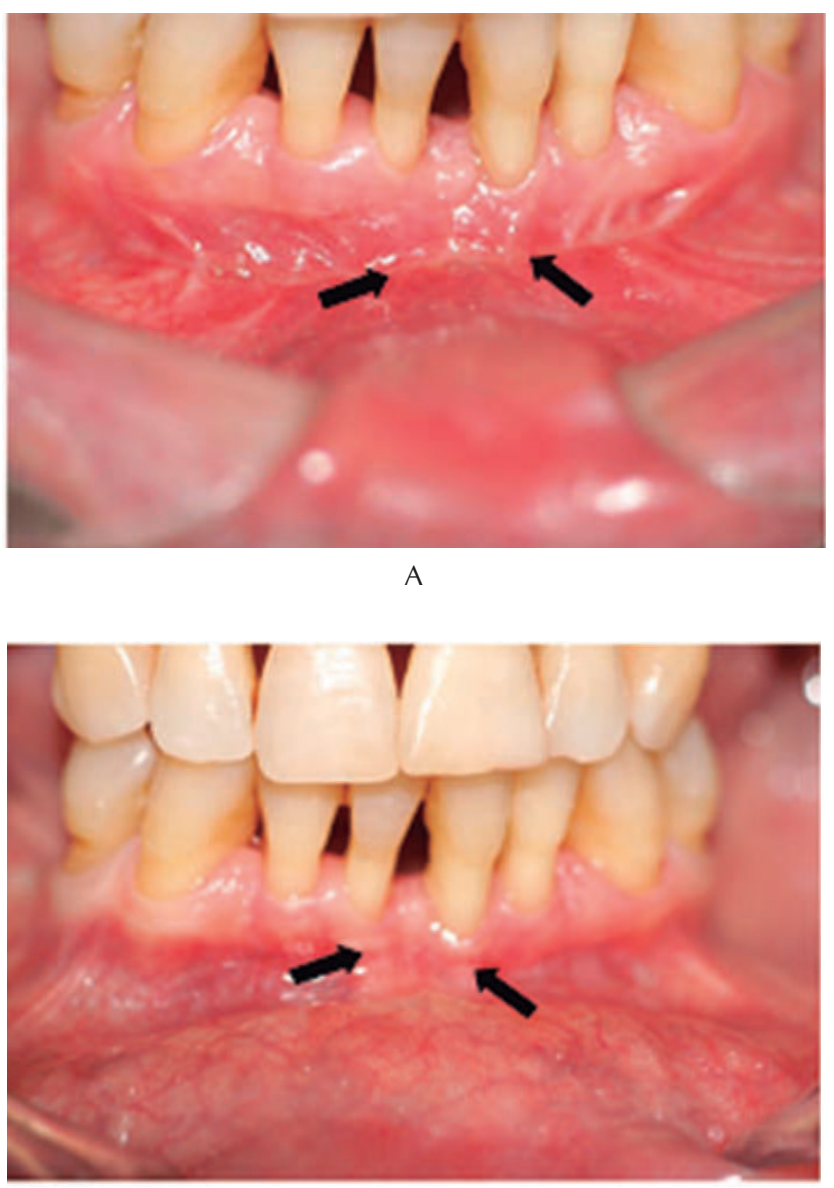

B

Figure 5 - A) Anterior aspect of the vestibule 9 months post-operatively. Note insertion line apically positioned (as indicated). B) Initial Presentation

\section{Discussion}

Some studies ${ }^{9,10-13}$ have demonstrated the suitability of biomembrana ${ }^{\mathrm{TM}}$ for stimulating neoangiogenesis, optimizing healing, reducing treatment time and improving patient comfort by protecting the treated area and not adhering to the adjacent tissues upon its removal. However, there are currently no reports on its use in the oral cavity. The present study has reported a total protection of the surgical wound by the biomembrana ${ }^{\mathrm{TM}}$, patient comfort and no adherence on membrane removal.

Sverzut et al. ${ }^{14}$ (2001) reported anterior mandible vestibluplasty in 13 edentulous patients using the Pichler and Trauner's technique (1939) as des- 
cribed by Howe ${ }^{5}$ (1965) and observed post-operative moderate edema and hematoma of the lip in 2 cases, yet no pain or esthetic complaints. In the present case, edema was mild, influenced by the membrane volume itself. No hematoma was observed and the patient did not complain of post-operative pain or esthetic issues. Sverzut et al. ${ }^{14}$ (2001) noted the persistence of a small scar in lowermost aspect of the sulcus after 180 days of surgery, which has been suggested as mild and insignificant. They have also reported that the appearance of the new alveolar ridge mucosa resembled that of the free mucosa rather than the attached gingiva. In this report, even 9 months after surgery, a tenuous scar line was observed and the aspect of the fixed mucosa was equivalent to that described by Sverzut et al. ${ }^{14}$ (2001).

Amato Filho and Donato ${ }^{1}$ (2002) published a literature review on vestibuloplasty and reported a case in the completely edentulous mandible using the same technique described in the present report. To protect the surgical wound and prevent healing contraction and consequent loss of sulcus depth they attached an immediate full denture to the site using steel wires for 2 weeks. In the current report, the use of a prosthetic appliance would have been unsuitable due to the presence of anterior teeth. In that sense, the latex biomembrane proved to be effective in protecting the surgical wound and maintaining sulcus depth.

Samandari et al. ${ }^{15}$ (2004) assessed the use of an amniotic membrane as a biodegradable graft in mandibular vestibuloplasty procedures in 7 edentulous patients, using Clark's technique. After a follow-up period of 6 months they reported a $17 \%$ to $40 \%$ reduction in vestibule depth. With the use of the Biomembrana ${ }^{\circledR}$ it has been possible to achieve a satisfactory level of stability, i.e., after a follow-up period of 9 months, a localized loss of $1 \mathrm{~mm}$ was observed adjacent to the teeth 41 and 31 . This positive outcome may have been influenced by the patient's adherence to the home physiotherapy program for at least the initial 2 weeks after membrane removal.

According to Beltrão e Marini ${ }^{2}$ (1986) there is a muscle tendency to regain its original insertion, which may lead to unsuccessful surgical attempts as a result of post-operative sulcus contraction. Metin et al. ${ }^{8}$ (2003) reported that surgical techniques relying on healing by second intention are inefficient due to the loss of vestibular depth during healing. For that reason they defend the use of techniques involving autogenous grafts. Following a retrospective study of 44 surgical procedures in 41 patients, all using autogenous grafts (full thickness skin, dermis, reverse dermis and palatal mucosa), they concluded that the best results in terms of color, blood supply and contraction were obtained from palatal mucosa grafts. Conversely, Sato ${ }^{16}$ (2002) reported that such type of graft presents some disadvantages, such as: two surgical sites, patient discomfort due to the open wound left in the palate and color contrast between the graft and neighboring tissues. Nonetheless Samandari et al. ${ }^{15}$ (2004) added that the palatal mucosa can only provide a limited amount of grafting tissue. Thus, the use of the Biomembrana ${ }^{\circledR}$ may become a plausible alternative. It is important to notice that the use of latex should be contra-indicated for people with known allergy to the material as was discussed by Netto and Mrue ${ }^{10}$ (2003).

\section{Final considerations}

Within the limitations of the present study, it can be concluded that the latex membrane Biomembrana ${ }^{\circledR}$ is an easy to use material which proved useful for vestibuloplasty, since it provided gain of attached gingiva, which remained stable during the 9-month follow-up period, however no gain of keratinized tissue was observed.

\section{Resumo}

Introdução: a biomembrana de látex Biomembrana ${ }^{\circledR}$ tem sido utilizada em diversas especialidades médicas, com resultados promissores em promover a cicatrização de feridas causadas por cirurgia, por trauma, por isquemia e induzidas por pressão, bem como ulceração de etiologia variada. No entanto, na odontologia, a sua utilização não está atualmente bem estabelecida. Objetivos: descrever um tratamento por vestibuloplastia, usando uma membrana de látex. Relato do caso: devido a características inerentes da biomembrana de látex (Biomembrana $\left.{ }^{\circledR}\right)$, uma vestibuloplastia do sextante anterior da mandíbula foi realizada, utilizando a técnica de Arruda por cicatrização por segunda intenção modificada pela utilização de uma biomembrana de látex, a fim de avaliar a sua aplicabilidade e capacidade para manter a profundidade do vestíbulo nesse tipo de cirurgia. Considerações finais: a membrana de látex, além de ser um material de fácil utilização e útil para cirurgia de vestibuloplastia, promoveu ganho de gengiva inserida, que permaneceu estável durante nove meses de acompanhamento.

Palavras-chave: Látex. Cirurgia bucal. Regeneração tecidual guiada, periodontal. Vestibuloplastia.

\section{References}

1. Amato Filho G, Donato AC. Vestibuloplastia mandibular: apresentação de caso pela técnica modificada de Arruda. Rev Paul Odontol 2002; 2(24):9-17.

2. Beltrão G, Marini, E. Aprofundamento de sulco vestibular. Odontol Clin Cient 1986; 1(1):38-45.

3. Genco RJ, Goldman, HM, Cohen DW. Periodontia contemporânea. 3. ed. São Paulo: Santos; 1999. 
4. Lindhe J, Karring T, Lang NP. Tratado de periodontia clínica e implantologia oral. 3. ed. Rio de Janeiro: Guanabara Koogan; 2005.

5. Howe GL. Preprosthetic surgery in the lower labial sulcus. Dent Practe 1965; 16(1):119-24.

6. Marzola C. Cirurgia pré-protética. 2. ed. São Paulo: Pancast; 1997.

7. Niccoli Filho WD, Seraidariam PI, Neisser MP, Kimpara ET, Rodrigues NAS, Marques ESB. Vestibuloplastia em maxila com laser de dióxido de carbono (CO2): relato de um caso. J Bras Odontol Clin 1998; 12(1):52-4.

8. Metin N, Dolanmaz D, Alkan A. Evaluation of autogenous grafts used in vestibuloplasty. J Int Med Res 2003; 31(1):3359 .

9. Lachat JJ, Mrué F, Thomazini JA. Morphological and biochemical characterization of a prosthesis manufactured from natural latex of Hevea braziliensis for medical utilization. Micron Microsc Acta 1997; 6(Suppl B):798-99.

10. Netto JC, Mrue F. Biomembrana ${ }^{\circledR}$ [Monografia]. São Paulo: Pelenova Biotecnologia S/A; 2003.

11. Potério Filho J, Silveira SF, Potério GM, Mrué F, Coutinho Netto J. O uso do látex natural com polilisina $0,1 \%$ na cicatrização de úlceras isquêmicas. In: $33^{\circ}$ Congresso Brasileiro de Angiologia e Cirurgia vascular; Belo Horizonte; 1999. Suplemento da Revista Brasileira de Angiologia e Cirurgia Vascular; 1999

12. Oliveira JAA, Hippolyto MA, Coutinho Netto J. La regeneration du tympan avec la utilization de matériel biosynthetique nouveau. In: $106^{\circ}$ Congrès Français D’Oto-Rhino-Laryngologie et chirurgie de la face et du cou; Paris/France; 1999.

13. Mrué F, Coutinho-Netto J, Ceneviva R, Tomazini JA, Lachat JJ. Novo método de reconstrução de defeitos extensos da parede abdominal e peritoniostomias. In: Congresso Mundial de Gastrocirurgia; Goiânia; 2001.

14. Sverzut CE, Gabrielli MFR, Gabrielli MAC, Barbeiro RH, Sverzut AT. Cirurgia pré-protética para aumento do sulco mandibular: avaliação clínica e radiográfica da profundidade do sulco mandibular anterior, após vestibuloplastia por inversão de retalhos: estudo em humanos. RGO 2001; 49(4):191-4.

15. Samandari MH, Yaghmaei M, Ejlali M, Moshref M, Saffar AS. Use of amnion as a graft material in vestibuloplasty: a preliminary report. Oral Surg Oral Med Oral Pathol Oral Radiol Endod 2004; 97(1):574-8.

16. Sato N. Cirurgia periodontal: atlas clínico. 1. ed. São Paulo: Quintessence; 2002.

\section{Address to:}

Jefferson Ricardo Pereira

Rua Recife 200, apto 601, Recife

88701420 Tubarão - SC

Fone: (48) 36222894 Fax: (48) 36264088

E-mail: jeffripe@rocketmail.com 